\title{
Research Article \\ Perceived Quality of a Virtual Community and Its Components: An Exploratory Investigation
}

\author{
Leila Othmani and Néji Bouslama \\ University of Tunis El Manar, Faculty of Economics and, management of Tunis, Tunisia
}

Correspondence should be addressed to: Leila Othmani; leila_oth@yahoo.fr

Received date: 6 March 2014; Accepted date: 18 July 2014; Published date: 24 June 2015

Academic Editor: Carlos Rompante da Cunha

Copyright (C) 2015. Leila Othmani and Néji Bouslama. Distributed under Creative Commons CC-BY 4.0

\begin{abstract}
The increasing use of the virtual communities encourages involvement in understanding its characteristics. The perceived quality of the website was a major concern of web marketer's. Given the differences between the traditional websites and the virtual communities, also the speedy maturation of information engineering, mechanisms of perception of quality has also evolved. This research identifies the specificities of perceived quality of virtual communities. Through an exploratory qualitative study in two stages we were able to extract five dimensions.
\end{abstract}

Keywords: virtual communities, perceived quality, social networking.

\section{Introduction}

Virtual communities have become increasingly popular involving several individuals of different cultures and civilizations. The growing rise of the use of new information technology has eliminated the distance between people (wind and Mahaja, 2002). Virtual communities are considered as an essential component of modern society, whether in the privacy of individuals or even in the activities of organizations.

Indeed, the rapid development of these communities has also influenced the behavior of users by allowing them to build a richer experience; companies can take advantage of virtual communities to increase sales (Brown, Tilton and Woodside, 2002) to benefit from positive word -of- mouth and potential (Bickart \& Schindler, 2001) and also to know the market trends (Bickart \& Schindler, 2001) or even to increase traffic in an e-commerce site (Bughin and Hagel, 2000).

It should be noted that previous studies on virtual communities have focused on understanding the nature of the participation and motivation of participants (Lee et al 2003. Ridings et al 2004. ). Thus, for this study we assume that a virtual community should be appreciated by the users for it to be beneficial. In the same context, "community manager" shall ensure the development of the quality of its community to improve the competitiveness of the company. To do this, it is important to know the dimensions of the quality of a virtual community. 
Certainly, a good knowledge of the mechanisms of virtual communities is crucial for the integration of members; their motivation and engagement in discussions (Maclaran and Catterall, 2002).

The objective of this study is to determine the dimensions of the quality of a virtual community.

We also try to provide a guide to help administrators of a virtual community to optimize the distinctive quality of their communities.

\section{Definitions of Virtual Communities}

Admittedly, the study of virtual communities is a complex task since it is a multi- facet concept, multi hardly controllable factors (Michail. K 2004). The term "virtual community" is defined as an aggregation that emerges in cyberspace when there is a combination of a sufficient number of members capable of performing discussions, share feelings enough to form webs of personal relationships (Rheingold, 1993). For their part, Fernback and Thompson (1995) defined it as the set of virtual social relationships forged in cyberspace through repeated contact without spatio- temporal boundaries and symbolically delineated by topic of interest community. After these first definitions, many authors have proposed other definitions. According to Balasubramanian and Mahajan (2001), a virtual community is a cyberspace allowing communication and interaction of participants. Another sizeable defined by Lee et al (2003): a virtual community is defined as a group of individuals or business partners who interact around a common interest where the interaction is partially or fully performed by electronic means. It is guided by some protocols or a few standards.

A more recent definition is that proposed by Mata and Quesada (2014). This definition considers the virtual communities as groups of persons who share for a common goals and interests and interact and communicate through the Internet.

Also, a virtual community can be defined as a group of individuals who share knowledge through electronic means such as an Internet network without physical presence (Kardaras et al. 2003).

A virtual community is a new commercial means of communication for a company to interact with its customers connected (HsiuFen, 2007).

\section{The Concept of Perceived Quality. :}

Perceived quality can be defined as the customer's perception of the overall quality of a good or as the superiority of a product or service on the trend of customer's choice (Aaker, 2011). Perceived quality is thus a general and intangible sense and it is not necessarily based on the knowledge of the client on the mundane features.

Giordano (2006) defines it as " all sensitive and sensory impressions, as well as clues that seduce and attract attention at first glance interpreted by the client as a promise of quality giving him confidence, and which satisfies him" (Giordano, 2006).

In addition, the perceived quality is a subjective judgment constructed in the mind of the user and it is him who determines its value where each dimension of a product or service may have a different perception of quality (Yu et al. 2005)

When it comes to the perceived quality of a website, one can notice a lot of research showing that the concept is multidimensional (Grose et al 1998. Vora , 1998; Ranganathan and Ganapathy, 2002; Moustakis et al. 2004). The majority of these studies show that the perceived quality varies with the user's expectations (Parasuraman et al, 1985. Gattorna and Walters, 1996).

\section{The Dimensions of the Perceived Quality of a Website. :}

Describing and improving the quality of electronic services have created a number of approaches that must be measured in terms of different dimensions often considerably relative to each other. 


\section{WebQualTM (2000)}

This scale is created by (Loiacono et al. ) (2000), according to this scale of measurement, the quality of a website is composed of twelve dimensions which are: 1 Quality of information, interaction, trust, response time, ease of use, design, simplicity, clarity, innovation, creativity, emotional aspect, the consistency of the image, the completeness of the online service and utility relative.

\section{WebQual (2001)}

According to Barnes and Vidgen, the concept of perceived quality online was designed on the basis of the communication; interactions and perceptions based on users (Barnes and Vidgen 2001). The concept of the quality perceived by the consumer line has three dimensions: the quality of information in the site, the quality of interaction and visual quality of the website.

\section{SITEQUAL (2001)}

The SITEQUAL was developed by Yoo and Donthu (2001) to measure the perception of the quality perceived by consumers.

According to this study; the concept of perceived quality has four dimensions. These are: ease of use, availability of information, the site appearance (color, creativity...) interactivity with consumers and the timeliness of responses, and finally safety.

\section{ETAILQ (2003)}

Wolfinbarger and Gilly (2003) consider that the perceived quality has four main dimensions, which are: the design of the website, the services offered to consumers online, reliability and security. For these authors, reliability and website design are the most important dimensions of perceived quality. They highly predict the consumer's judgment on the perceived quality and satisfaction.

\section{Methodology}

In the absence of a strong conceptual basis on the quality of virtual communities, the exploratory study is essential to develop the quality dimensions of a virtual community as perceived by consumers, and to Perrien Al (1984), " qualitative approach sees the

individual as a complex entity, difficult to quantify, that through his own experiences will shape his environment with all the subjectivity inherent in understanding and interpreting the events as " exploratory approach is generally a preamble to a quantitative research . " (Perrien et al., 1984)

The methods used in the qualitative phase aimed to let the interviewees speak freely on specific topics in order to obtain maximum information. To obtain this information necessary for marketing activities, three main types of collections are available for qualitative research which are: individual interviews (unstructured, semi structured), projective tests (individual or group) and group meetings.

As part of this research, the methodology is a qualitative study in two phases based on two different types of collections:

- A group meeting

- A semi-structured individual interview series

\section{Discussion Groups}

Focus groups were used to provide data for the development of a conceptual model of website quality. Flick (1998) and Neuman (1997) suggested that focus groups are useful in exploratory research or to generate new ideas for assumptions.

A Facebook group of 20 people was created for this study. All participants have experience in virtual communities, and 15 of them had experience as a "community manager".

We asked each member to choose an existing virtual community on Facebook and submit them to the other members to discuss the positive and negative aspects of each community. Thus, we asked each member to identify the positive and 
negative characteristics of each community, to state the reasons for choosing these criteria and rank them according to importance.

\section{The Semi-Structured Interview:}

The use of semi-structured interviews aims at exploring the dimensions of the quality of a virtual community in-depth. A sample of 24 people was selected; these entire people (12 men and 12 women) visit regularly and actively participate in virtual communities. We chose a heterogeneous sample while respecting the criteria of relevance that reflect a diversity of opinion on the subject of our research. Our sample consists of individuals aged 25 and 55, students, graduates and active "experienced", but all are administrators or members of several virtual communities. During these interviews; we asked interviewees to answer the following questions:

According to you:

What is a virtual community of quality?

What are its characteristics?

\section{Qualitative Analysis}

Data were coded individually for consistency. The importance of each dimension was determined by the frequency of citation and its ranking in the speech. Various determinants fused to different stages in the discussion, and three coding steps were used for data analysis.

After preparing the data and to better understand the content of the surveys, we conducted multiple readings of texts. We also summarized talks to facilitate the processing of information in the following steps of the analysis.

Then, text segments meaningful to the objectives of the study were identified. These segments were organized under various themes set of expressions reflecting the unity of meaning of the whole text) to try to fix the database by subject.

During the last step, we conducted a "refinement of the categories" developing subcategories "including conflicting views and new perspectives". We also chose the most representative texts of the essence of these categories. In this process, similar categories were combined or reorganized for better presentation.

\section{Results and Discussion}

In this section, we present the main results and lessons learned from this research. Two levels of analysis were selected. The first level was the analysis of the discussion panel, and a second level of analysis of individual interviews online.

\section{Summary of Results}

It is recognized that clients often share the dimensions of service quality in various dimensions (Carman, 1990) and a hierarchical conceptualization of quality of service is appropriate (Brady and Cronin, 2001).

We will sum up in our study five dimensions associated with the perceived quality of a virtual community, namely: the quality of the members forming the community, quality of content, the popularity of virtual community, interactivity, and safety (Figure 1) 


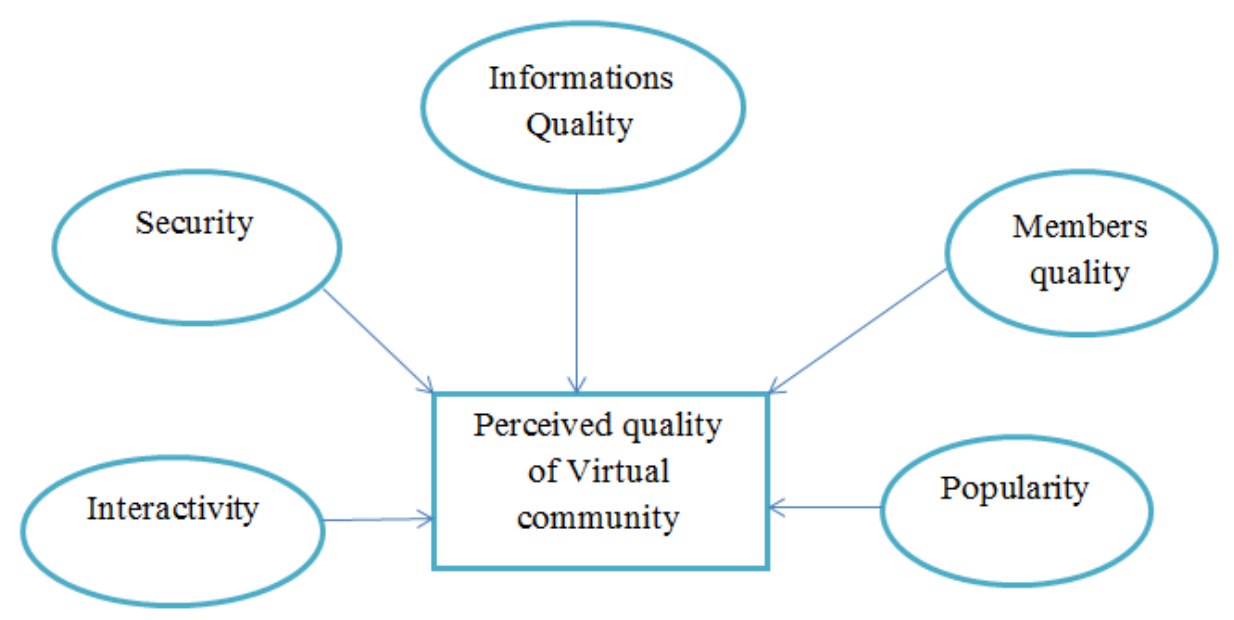

Figure 1: Dimensions of the Perceived Quality of a Virtual Community

Customers often share the dimensions of service quality in various sub - dimensions (Carmant, 1990). There is talk of a hierarchical conceptualization of quality of service is appropriate (Brady and Cronin, 2001).

\section{The Quality of Members:}

Unlike a web 1.0 website, in a virtual community we can know the members that make up this community and even their characteristics (level of expertise, seriousness, and sometimes social class). Thus, in our study the quality of members who form a virtual community is the main dimension of perceived quality cited by 80 $\%$ of respondents.

One of the main characteristics of virtual communities is the generation of content by users who participate to enrich their knowledge, exchange or solve their problems (Hsua et al 2007) and unlike a traditional website. Users are known and can affect the overall perception of this community.

For example one interviewee stated "I enjoy this community because $\mathrm{Mr} \mathrm{X}$ is a member " It is recognized in marketing consumer preferences are influenced by their reference groups such as social classes, ethnic groups, the family, friends ... "At the consumer relations may limit the options of his" ego " and influence their choices, just as providing him with opportunities to promote his interests and influence on others " ( Sempé 2000) The complexity of the assessment of a virtual community lies indeed in its multimember ship and it is therefore subject to different pressures more or less implicit such as the presence of social references in this community.

Table 1: The Quality of Members

\begin{tabular}{|l|l|l|}
\hline Examples of verbatim & $\begin{array}{l}\text { Percentage of } \\
\text { respondents }\end{array}$ & Coverage \\
\hline $\begin{array}{l}\text { "A good virtual community is represented by } \\
\text { experts who are serious, helpful, present known } \\
\text { belonging to our frame of reference..." }\end{array}$ & $80 \%$ & $\begin{array}{l}16 \text { encoded references } \\
\text { [18.43 \% Cover] }\end{array}$ \\
\hline
\end{tabular}




\section{Interactivity:}

Interactivity can be defined according to three approaches: as a technological aspect, as a process of exchanging messages or as the perception of a user of an information exchange process (McMillan \& Hwang, 2002).

As the quality of member interactivity is a feature usually associated with virtual communities (Leiner and Quiring 2008), interactivity is the ease of direct communication between several undertakings or users without spatiotemporal constraints (Blattberg and Deighton 1991). So this is the ability of users to share and edit content to a real time (Steuer, 1992) which is the exchange between a transmitter of content and a match. Numerous studies have also identified that interactivity helps to build a good relationship with customers in large firms (Ghose and Dou, 1998). On social networks, it is more about interactivity between users, or "user -user interctivity ", represented by a collaborative exchange between two or more users. (Mahmoud and Auter 2009) This gives users more freedom in changing and exchanging messages (recommendation, comments....). To satisfy their need Liu and Shrum 2002). Some researchers have shown that the interaction can have a positive impact on the attitudes of the user (Wu 1999) as in the context of the present study, $70 \%$ of respondents cited that interactivity is an important quality in a virtual community.

Table 2: Interactivity

\begin{tabular}{|l|l|l|}
\hline Example of verbatim & $\begin{array}{l}\text { Percentage } \\
\text { of } \\
\text { respondents }\end{array}$ & Coverage \\
\hline $\begin{array}{l}\text { "The quality of a community depends } \\
\text { on the frequency of sharing and } \\
\text { interaction... repetitions of interactions } \\
\begin{array}{l}\text { and cooperation... Also different } \\
\text { interactions I have with its members" }\end{array}\end{array}$ & $\begin{array}{l}\text { § } 15 \text { encoded } \\
\text { references }[15.87 \% \\
\text { Cover] }\end{array}$ \\
\hline
\end{tabular}

\section{The Quality of Information:}

The quality of information on a website, and the inherent value and usefulness of the content on a website (Huizingh 2000) are the perceived values of the users of a website or a virtual community.

Traditionally the quality of information is one of the main dimensions of the perceived quality of a website (Subramanian et al., 2014 Ho and Lin 2010 Katerattanakul and Siau 1999, Strong et al. 1997...) . Just like a traditional website, quality information in a virtual community has been a fundamental axis of the perceived quality. In this study,
$65 \%$ of respondents agree on the fact that a virtual community must have a rich, relevant, useful, and reliable quality content. However, the content of a virtual community is mostly created by users and therefore difficult to control. Consequently, the user perception of the quality of information in virtual communities may be different than in traditional websites because users can freely express their opinions. They therefore expect to find reliable, relevant information from several sources (friends, business, expert) and detailed information that can improve their understanding and decisions. 
Table 3: The Quality of Information

\begin{tabular}{|l|l|l|}
\hline Verbatim Example & $\begin{array}{l}\text { Percentage of } \\
\text { respondents }\end{array}$ & Coverage \\
\hline $\begin{array}{l}\text { " The quality of a community depends on } \\
\text { the importance of reliable information for } \\
\text { me... its content should be rich and } \\
\text { useful" }\end{array}$ & $65 \%$ & $\begin{array}{l}13 \text { encoded } \\
\text { references [11.63\% } \\
\text { Cover] }\end{array}$ \\
\hline
\end{tabular}

\section{Security:}

The perceived security can be defined as the degree of consumers' reassurance when using technology which is reassuring (Du et; Shin 2009; Chiu et al 2009. Strutton and Taylor 2010). Security is a major challenge for webmarketer because any event can cause heavy losses for the company (and Eleonora Di Pietro 2012) on virtual communities safety. The analysis of the interviews showed that, like a traditional website for a virtual community, the level of perceived security can be seen as a determinant of the quality of a virtual community; and $60 \%$ of respondents expressed that they prefer communities that respect the privacy of members, who control their content to avoid the presence of dubious link and spammed.

Table 4. Security

\begin{tabular}{|l|l|l|}
\hline Verbatim Example & $\begin{array}{l}\text { Percentage of } \\
\text { respondents }\end{array}$ & Coverage \\
\hline $\begin{array}{l}\text { " This community should not send } \\
\text { spam, undesirable or offensive } \\
\text { messages all the time. " }\end{array}$ & $60 \%$ & $\begin{array}{l}12 \text { encoded } \\
\text { references } \\
\text { [11.05\% Cover] } \\
\text { or questionable links " }\end{array}$ \\
\hline
\end{tabular}

\section{Popularity:}

"It's easier to appreciate a community that has 20,000 members than a community that has less than 100 members." This is what interviewees replied.

Unlike a traditional website, a single user can easily know the number of people belonging to this community, and the number of people who speak about it.
According to Freud (1921) in a crowd, the individual is not aware of his actions; he is struggling with the suggestion that abolishes his discretion, but may instead reveal another "faculties" in extreme exaltation (Freud, 1921). " In a crowd, every feeling is contagious to the point that the individual easily sacrifices his personal interest to the collective interest" Freud, 1921). This dimension is cited by $35 \%$ of respondents as shown in the joined table. 
Table 5: Popularity

\begin{tabular}{|l|l|l|}
\hline Verbatim Example & $\begin{array}{l}\text { Percentage } \\
\text { of } \\
\text { respondents }\end{array}$ & Coverage \\
\hline $\begin{array}{l}\text { "The quality of a community depends } \\
\text { on the number of friends belonging to } \\
\text { this community, thus popularity } \\
\text { shows that this community is } \\
\text { trustworthy" }\end{array}$ & $35 \%$ & $\begin{array}{l}\text { 7 encoded } \\
\text { references [5.38\% } \\
\text { Cover] }\end{array}$ \\
\hline
\end{tabular}

\section{Conclusion}

Virtual communities are an effective tool for business development (Lu et al. , 2010). It is clear that these communities represent a real opportunity for companies to get closer to their customers and even understand the market trends, but attracting new members and retaining existing members is not an easy task (Harris and Good, 2004). That is why our research objectives are to explore and describe the dimensions of the perceived quality of a virtual community. In one approach of qualitative and interpretive research (Lawrence Neuman, 2001), we conducted a qualitative study on two stages, a group meeting and a series of individual interviews online to identify the different facets of the problem.

Data processing was performed using the NVIVO 8 software by following the three steps recommended by Miles and Huberman (2003), namely, data condensation and representation, development, and verification of conclusions.

We have emerged five dimensions of perceived quality of a virtual community. It is the quality of the members in this community, the quality of content, the popularity of virtual community, interactivity, and security.

This study is very important because it gives companies a better view of the current framework of web marketing, and because of the paucity of studies on the perceptual mechanisms in virtual communities.

However, due to the exploratory nature of this research, and the lack of literature in this area, there are limitations to this study, and research opportunities are promising.
First, the model of the perceived quality of a virtual community (Figure 1) did not provide specific measurement scales. It is necessary to develop an appropriate instrument of measurement to help companies on social networks know their market and improve their image...

Thus, it is necessary to build a reliable and accurate instrument for researchers to apply in different aspects and behavioral mechanisms in virtual communities.

A quantitative study would be desirable to develop this scale of measurement to confirm dimensions

Second, the dimensions presented in this article are ranked according to their importance, as perceived by respondents. It would be interesting to evaluate the classification statistically.

This could be useful for companies on social networks to understand the priorities of the consumers who are members of virtual communities.

\section{References}

1.Aaker D. (2011). 'Perceived Quality,' The Free Press, New York.

2.Balasubramanian, S., \& Mahajan, V. (2001). 'The Economic Leverage' of the Virtual Community," International Journal of Electronic Commerce, 5 (3). pp. 103-138.

3.Barnes, S. J. \& Vidgen, R. T. (2001,). "Assessing the Quality of Auction Web Sites," In System Sciences, 2001. Proceedings of the 34th Annual Hawaii International Conference on (pp. 10-pp). IEEE. 
4.Bernard, H. R., \& Bernard, H. R. (2012). 'Social Research Methods: Qualitative and Quantitative Approaches,' Sage.

5.Bickart, B. \& Schindler, R. M. (2001). "Internet Forums as Influential Sources of Consumer Information," Journal of Interactive Marketing, 15, 31-40.

6.Blattberg, Robert C. \& John Deighton (1991). 'Interactive Marketing: Exploring the Age of Addressability,' Sloan Management Review, 33, 1, 5-14.

7.Brady M. K. et Cronin J. J. (2001). "Some New Thoughts on Conceptualizing Perceived Service Quality: A Hierarchical Approach," Journal of Marketing, 65, Juillet, 34-49.

8.Brown, S. L., Tilton, A., \& Woodside, D. M. (2002). 'The Case for Online Communities,' The McKinsey Quarterly, 1.

9.Bughin, J., \& Hagel, J. (2000). 'The Operational Performance of Virtual Communities,' International Journal of Electronic Markets and Business Media, Dec.

10.Carman J. M. (1990). "Consumer Perceptions of Service Quality: An Assessment of SERVQUAL Dimensions," Journal of Retailing, 33-55.

11.Chiu, C.M., Chang, C. C., Cheng, H. L., \& Fang, Y.H. (2009). "Determinants of Customer Repurchase Intention in Online Shopping," Online Information Review, 33 (4). 761-784.

12.Fernback, J., \& Thompson, B. (1995). 'Virtual Communities: Abort, Retry, Failure?,'

13.Flick, U. (1998). 'An Introduction to Qualitative Research,' London : Sage.

14.Freud, Sigmund (1921). The Leader and His Crowd: Sigmund Freud's Group. Psychology and the Analysis of the Ego, dalam J.S. McClelland (ed). A. History of History of Western Political Thought, London: Routledge.

15.Gattorna, L., Walters, W., 1996. "Managing the Supply Chain: A Strategic
Perspective". Macmillan Business, Basingstoke.

16.Ghose, S. \& Wenyu D. (1998). "Interactive Functions and Their Impacts on the Appeal of Internet Presence Sites," Journal of Advertising Research, 38 (2). 29-43.

17.Giordano, J.L. (2006). "L'approche Qualité Perçue," Groupe Eyrolles, ISBN : 27081-3493-0. $380 \mathrm{p}$.

18.Grose, E., Forsythe, C. \& Ratner, J. (1998). 'Using Web and Traditional Style Guides to Design Web Interfaces,' C., Forsythe, C., Ratner, J. (Eds.). 'Human Factors and Web Development'. Lawrence Erlbaum Associates, New Jersey, pp. 121131.

19.Harris, L.C. \& Goode, M. M. H. (2004). "The Four Levels of Loyalty and the Pivotal Role of Trust: A Study of Online Service Dynamics," Journal of Retailing, Vol. 80 No. 4, pp. 139-58.

20.Ho, C.B., \& Lin, W. (2010) "Measuring Service Quality of Internet Banking: Scale Development and Validation," European Business Review, Vol. 22, No. 1, pp. 5-24.

21.Lin, H. F. (2007) "Knowledge Sharing and Firm Innovation Capability: An Empirical Study," International Journal of Manpower, Vol:28 No:3/4 (2007) (315-332)

22.Lin, H. F. (2007). "The Role of Online and Offline Features in Sustaining Virtual Communities: An Empirical Study," Internet Research, Vol. 17 Iss: 2, pp.119-138.

23.Hsu, M., Ju, T. L., Yen, C. H., \& Chang, C. M. (2007). "Knowledge Sharing Behavior in Virtual Communities: The Relationship between Trust, Self-Efficacy, and Outcome Expectations," International Journal of Human-Computer Studies, 65(2). 153-169.

24.Huizingh, E.K.R.E. (2000). "The Content And Design Of Web Sites: An Empirical Study," Information \& Management 37 (3) : $123-34$

25.Giordano, J.L. "L'Approche Qualité Perçue," Éditions d'Organisation', 2006. 
26.Kalogiannakis, M. (2004). 'Réseaux Pédagogiques et Communautés Virtuelles: de Nouvelles Perspectives pour les Enseignants,' Paris : L'Harmattan.

27.Kardaras, D., Karakostas, B. \& Papathanassiou, E., (2003). "The Potential of Virtual Communities in the Insurance Industry in the UK and Greece," 23, 41-53.

28.Katerattanakul, P. \& Siau, K. (1999). "Measuring Information Quality of Web Sites: Development of an Instrument," International Conference on Information Systems, Charlotte, NC, pp. 279-285.

29.Lee, F. S., Vogel, D., \& Limayem, M. (2003). "Virtual Community Informatics: A Review and Research Agenda," Journal of Information Technology Theory and Application, 5 (1). 47-61.

30.Leiner, D. J. \& Quiring, O. (2008). "What Interactivity Means to the User: Essential Insights and a Scale for Perceived Interactivity," Journal of Computer-Mediated Communication

31.Liu, Y., \& Shrum, L. J. (2002). "What is Interactivity and Is it Always Such a Good Thing? Implications of Definition, Person, and Situation for the Influence of Interactivity on Advertising Effectiveness," Journal of Advertising, 31(4). 53-64.

32.Loiacono, E. T. ; Watson, R. T. ; Goodhue, D. L. (2007). 'WebQual: An Instrument for Consumer Evaluation of Web Sites,' International Journal of Electronic Commerce 11(3) : 51-87. doi : $10.1108 / 14635770910948259$.

33.Lu, Y., Zhao, L., \& Wang, B. (2010). "From Virtual Community Members to C2C ecommerce buyers: Trust in Virtual Communities and its Effect on Consumers' Purchase Intention," Electronic Commerce Research and Applications, 9, 346-360.

34.Maclaren, P. \& Catterall, M. (2002). "Researching the Social Web: Marketing Information from Virtual Communities," Marketing Intelligence and Planning, Vol. 20 No. 6, pp. 319-326.

35.Mata, F. J. \& Quesada, A. (2014). "Web 2.0, Social Networks and E-commerce as Marketing Tools," Journal of Theoretical and Applied Electronic Commerce Research, 9/ISSUE 1/ 56-69

36.McMillan, S.J. \& Hwang, J.-S. (2002). "Measures of Perceived Interactivity: An Exploration of the Role of Direction of Communication, User Control, and Time in Shaping Perceptions of Interactivity," Journal of Advertising, 31(3). 41-54.

37.Miles, M. B. \& Huberman A. M. (2003). "Analyse des Données Qualitatives, “ '(2ème édition). de boeck.

38.Moustakis, V., Litos, C., Dalivigas, A., Tsironis, L., (2004). 'Website Assessment Criteria,' Proceedings of International Conference on Information Quality, Boston: MIT, November 5-7, pp. 59-73.

39.Pantano, E., \& Di Pietro, L.D. (2012). “Understanding Consumer's Acceptance of Technology-Based Innovations in Retailing," Journal of technology management \& innovation, 7(4). 1-19.

40.Parasuraman, A., Zeithaml, V.A., Berry, L.L. (1985). "A Conceptual Model of Service Quality and Its Implications for Future Research," Journal of Marketing 49, 41-50.

41.Perrien J., Cheron E. \& Zins M. (1984). 'Recherche en Marketing, Ed Gaétan Morin, Bouchuville,' Québec, Canada.

42.Rheingold, H. (2000). "The Virtual Community: Homesteading on the Electronic Frontier," (No. 28). MIT Press.

43.Ridings, C.M. \& Gefen, D. (2004). "Virtual Community Attraction: Why People Hang Out Online," Journal of Computer-Mediated Communication, Vol. 10, No. 1, Article 4.

44.Sempé L. (2000). "Une Analyse de Mesure de L'appartenance aux Cercles Sociaux: Une Analyse Factorielle Mutiniveaux," Recherche et Applications en Marketing, 15, 2, 43-58.

45.Steuer, J. (1992). "Defining Virtual Reality Dimensions Determining Telepresence," Journal of Communication,42 (4).73-93 
Strong, D.M., Lee, Y.W. \& Wang, R.Y. "Data Quality in Context," Communications of the ACM (40:5) 1997, pp 103-110.

46.Subramanian, N., Gunasekaran, A., Yu, J., Cheng, J. \& Ning, K. (2014) "Customer Satisfaction and Competitiveness in the Chinese E-Retailing: Structural Equation Modeling (SEM) Approach to Identify the Role of Quality Factors," Expert Systems with Applications, Volume 41, Issue 1, January 2014, Pages 69-80,21st Century Logistics and Supply Chain Management

47.Sumber: Mahmoud, A. E.-B., \& Auter, P. J. (2009). "The Interactive Nature of Computer-Mediated Communication," American Communication Journal , 11 (4).

48.Taylor, D. G. \& Strutton, D. (2010). "Has e-marketing Come of Age? Modelling Historical Influences on Post-adoption era Internet Consumer Behaviours," Journal of Business Research, 63, 950-956.

49.Thompson, S.A. \& Sinha, R.K. (2008). "Brand Communities and New Product Adoption: The Influence and Limits of Oppositional Loyalty," Journal of Marketing, Vol. 72 No. 6, pp. 65-80.

50.Vora P. (1998). 'Human Factors Methodology for Designing Web Sites,' in: E.
Grose, C. Forsythe, J. Ratner (Eds.). Human Factors and Web Development, Lawrence Erlbaum Associates, New Jersey, pp. 189198.

51.Wind, Y. \& Mahajan, V. (2002). "Convergence Marketing," Journal of Interactive Marketing, 16 (2). 64-79.

52.Wolfinbarger, M.F. \& Gilly, M.C. (2003). "ETAILQ: Dimensionalizing, Measuring and Predicting E Tailing Quality," Journal of Retailing, 79(3). 183198.

53.Wu, Guohua (1999). 'Perceived Interactivity and Attitudes toward Web Sites,' in Proceedings of the 1999 Conference of the American Academy of Advertising, Marilyn S. Roberts, ed., Gainesville, FL: American Academy of Advertising, 254-262.

54.Yoo B. \& Donthu N. (2001). 'Developing a Scale to Measure the Perceived Quality of Internet Shopping Sites (SITEQUAL),' Quarterly Journal of Electronic Commerce, 2(1). 31-47.

55.Yu, S., Al-Jadir, L. \& Spaccapietra, S. (2005, May). "Matching user's Semantics with Data Semantics in Location-based Services," In Workshop on Semantics in Mobile Environments (SME 2005). 